\title{
Management of birth, postpartum care and breastfeeding - Polish recommendations and guidelines during SARS-CoV-2 pandemic
}

\author{
Katarzyna M.Wszolek®, Karolina Chmaj-Wierzchowska®, Maciej Wilczak® \\ Department of Maternal and Child Health, Poznan University of Medical Sciences, Poland
}

\begin{abstract}
SARS-CoV-2 pandemic is an unusual phenomenon in the modern obstetric and midwifery history. Hospital staff from the isolation wards were trained in the safety and proper use of the hazardous materials suit and the proper managing of the biohazard materials. We were not expecting the situation, so we started to create more restrictions than facilities for mothers giving birth. In the context of infection risk for the fetus, scientists still search for vertical transmission evidence, but available data are ambiguous, and more research is needed. Concerning the infant safety and to minimalize the infection risk for medical teams, the first Polish guidelines published by the national consultants in obstetrics, midwifery, neonatology, and perinatology regarding the safest formula of birth were as the following: in the case of confirmed SARS-CoV- 2 infection, the cesarean section for epidemic indications should be considered, except in an advanced or rapid labor. In the lately updated consensus ( $14^{\text {th }}$ May), it was written that because the risk of vertical and intranatal SARS-CoV- 2 transmission seemed to be low, the SARS-CoV-2 infection was not the main indication to perform cesarean section for any longer. Regardless of the birth formula, the newborns are separated from their mothers immediately after the labor in Polish obstetrician hospitals. The Polish Lactation Study Centre, consociating International Breastfeeding Certified Lactation Consultant, recommends feeding the newborn with its own mother's milk, even if she is infected with SARS-CoV-2 and isolated from her infant.
\end{abstract}

Key words: pregnancy; newborn; SARS-CoV-2; Polish guidelines

Ginekologia Polska 2021; 92, 5: 387-391

\section{INTRODUCTION}

SARS-CoV-2 pandemic is an unusual phenomenon in the modern obstetric and midwifery history. We were not expecting the situation, so we started to create more restrictions than facilities for mothers giving birth.

In Poland, we approved the COVID-19 case definition as was proposed by the World Health Organization (WHO), adapted also by the European Centre for Disease Prevention and Control (ECDC) in which three clinical situations were distinguished: a suspected case, a probable case, and a confirmed case [1]. A suspected case is also defined as a neonate born to a mother with a history of 2019-nCoV infection between 14 days before delivery and 28 days after delivery, or the neonate directly exposed to those infected with 2019-nCoV (including family members, caregivers, medical staff, and visitors) [2].

Pregnant women do not seem to be more likely to have SARS-CoV-2 infection than the general population, and it was confirmed in a large study of 16,749 patients with COVID-19 hospitalized in the United Kingdom. The proportion of pregnant women with SARS-CoV-2 infection (6\%) was comparable to the proportion in the general population. Moreover, pregnancy was not associated with increased mortality. Another noteworthy observation was made in New York, where a group of 215 women in attendance for childbirth were screened for SARS-CoV-2 infection over a two-week period (nasopharyngeal swab) and $15.4 \%$ of them were tested positive for SARS-CoV-2 infection. Of those 215 women, only four (1.9\%) presented COVID-19 symptoms, while most were asymptomatic [3]. Scientists still search for vertical transmission evidence, but available data are ambiguous, and more research is needed [4].

\section{RECOMMENDATIONS}

The first public restrictions in Poland started on $13^{\text {th }}$ March, when the Polish government announced the Risk of Epi-

\footnotetext{
Corresponding author:

Katarzyna Maria Wszolek

Department of Maternal and Child Health, Poznan University of Medical Sciences, Poland

e-mail: polozna.kasia.wszolek@gmail.com
}

This article is available in open access under Creative Common Attribution-Non-Commercial-No Derivatives 4.0 International (CC BY-NC-ND 4.0) license, allowing to download articles and share them with others as long as they credit the authors and the publisher, but without permission to change them in any way or use them commercially. 
demic Status (Journal of Laws of the Republic of Poland, No 2019.1239) [5]. Within this act, some regulations were crucial for the health service functioning, especially:

- The duty of undergoing a health examination or applying other prophylaxis measures by the infected or suspected of being infected persons or those being in the group of high risk of infection [46 b. (4) section of act].

- The duty of quarantine [46 b. (5) section of act].

- The type and extent of patients' medical history, including personal data protection and information regarding the patients' health status ( 46 ba. section of act).

- A list of hospitals which had to be transformed into isolation hospitals.

On $20^{\text {th }}$ March, the Polish government announced the Epidemic Status (the Ministry of Health Regulation, $20^{\text {th }}$ March: Journal of Laws of the Republic of Poland, No 491) [6].

Since that time, all hospitals were obliged to modify their procedures, especially:

1. Admission to a hospital [7]

- Triage must be held in special restricted areas. The medical staff is obligated to use the means of personal protection - certified face masks, face shields, or goggles. A temperature measurement is obligatory as well as a patient's epidemiology anamnesis.

- Patients in the low-infection-risk group are admitted to hospital in the special areas for low-risk patients, and patients from the high-risk group (elevated body temperature, contact with infected person, the fact of quarantine) are to be directed to the special wards - dedicated for the infected patients or suspected of being infected.

- The next step is taking a nasopharyngeal swab from patients in the high-risk group and sending the specimen to a sanitary-epidemiological station. During the time of waiting for the swab result, the medical staff is obligated to follow the safety rules (using the means of personal protection - certified face masks with FFP2/FFP3 or N95 filter, face shields, or goggles). Patients are obligated to use a certified face mask (with FFP2/FFP3 or N95 filter).

The obstetrician hospitals were obliged to modify their procedures and aforementioned areas. We split the E\&A into two separate areas. In the area for the infected patients or patients from the high-risk group of infection, we can perform cardiotocography, ultrasounds, childbirth, and cesarean section. The hospital staff from the isolation wards were trained in the safety and proper use of hazardous materials suits and the proper managing of the biohazard materials (e.g., blood).

2. Childbirth

- The Polish national consultant in midwifery and obstetrics, the national consultant in neonatology, the national consultant in perinatology, the chairperson of Polish Association of Gynecologists and Obstetricians, the chairperson of Polish Association of Neonatologists, and the chairperson of Polish Association of Perinatal Medicine concerning a childbirth in the dedicated isolation ward for pregnant women in the case of the suspicion of SARS-CoV-2 infection or confirmed infection: In the case of confirmed SARS-CoV-2 infection, the cesarean section for epidemic indications should be considered, except in an advanced or rapid labour. [...] The argument for the cesarean section is:

I. The possibility of the fetus being infected in the birth canal or the general area (urinary tract, gastrointestinal tract). [...] the discharges amount is reduced during the cesarean section.

II. [...] a significant risk for medical staff - obstetricians and midwives. A much longer natural childbirth (with more than one staff shift) and a reduced amount of means of personal protection and the staff' exposer time is significantly difficult and leads to a higher risk of quarantine for the medical staff, which reduces a possibility to giving care for the other infected patients. Moreover, the medical staff is not able to look after other, not-infected patients" [8].

- In the most recently updated national obstetrics, gynecology, and perinatology consensus, issued on $14^{\text {th }}$ May, it is written that because the risk of vertical and intranatal SARS-CoV-2 transmission seems to be low $[9,10]$, the SARS-CoV-2 infection is not the main indication to perform cesarean section currently. Under the obstetrician's consideration remains the final decision (the local wards and staff work organization and patient's clinical situation as well) [10].

- Since $16^{\text {th }}$ April, according to The Council of Ministers Regulation [11], the face and nose covering is mandatory: 2) in public places, including: b) in establishments of employment and public buildings dedicated to: [...] health service centers [...]". It means that even women during the childbirth should be encouraged to use a face mask.

This regulation was very controversial for pregnant women in Poland. The Childbirth with Dignity Foundation (the organization campaigning for the pregnant and delivering women rights in Poland) took a stand against this law and wrote an official statement to the Ministry of Health [12]. The reply from the Ministry of Health was equivalent in meaning. Since $28^{\text {th }}$ April, a healthy woman during the first, second, or third stage of childbirth does not have to cover her face or nose under the condition of staying in an individual delivery room. Moreover, this 
exception does not concern the infected patients or women under the quarantine period [13].

- Family childbirths were suspended since $13^{\text {th }}$ March, when the Polish government announced the Risk of Epidemic Status in the country. The first actualization was published on $5^{\text {th }}$ May [14]. The national consultant in obstetrics and gynecology and the national consultant in perinatology recommend:

- The epidemiological questionnaire should be filled by the patient and her accompanying person.

- The accompanying person is obligated to use a face mask all the time during his/her presence in the hospital.

- The accompanying person should have an actual nasopharyngeal swab result for SARS-CoV-2, and the swab result is valid only for 5 days.

- The patient and her accompanying person should stay in an individual delivery room with the separate sanitary unit.

- The accompanying person may come into the delivery room when the childbirth starts and should leave the hospital in two hours'time after the labor.

- The persons isolated or under the quarantine period cannot be present during the childbirth.

- The final decision about family childbirths is made by the hospital chairman.

- Visits in the hospital wards are suspended.

3. Postpartum period

a) Management of infants born to mothers with the COVID-19 infection or mothers suspected to be infected.

The procedure of separation of newborn from its mother (SARS-CoV-2 positive or suspected) immediately after the labor is practiced in Polish obstetrician hospitals, as suggested by some authors [15], but this procedure does not comply with the WHO mothers' recommendations according to which a mother can hold her newborn skin-to-skin and share room with her own baby [16]. The Centers for Diseases Control and Prevention also recommends giving a choice to the mother whether she prefers a temporary separation from her newborn in hospital. If her choice is to stay with the baby, then a two-meter distance is recommended. Additionally, some physical barriers (such as a curtain) may be indicated to minimize the risk of virus transmission. The mother should wear a face mask and wash her hands frequently [17].

The Polish mothers report separation as an extremely soul-crushing and oppressing procedure.
We strongly believe that Polish hospitals can change this policy because research results are reassuring and the newborn separation from its own mother should not be a standard practice in defiance of WHO recommendations.

b) Breastfeeding.

The Polish Lactation Study Centre, consociating International Breastfeeding Certified Lactation Consultant, recommends feeding the newborn with its own mother's milk, even if she is infected with SARS-CoV-2 [18]. Until now, there is no scientific evidence of virus' presence in mother's milk. Moreover, only the SARS-CoV-2 antibodies were found. TheWHO states that mothers with confirmed SARS-CoV-2 infection can breastfeed their infants [16].

The Polish guidelines for mothers are:

a) Breastfeeding and general rules [18]:

- Before breastfeeding and any contact with the baby, the mother should wash her hands for at least 30 seconds, using a detergent or an alcohol-based disinfectant, cover her face using a disposable face mask (utilize it only for single use) [...].

- An infant may stay in one room with the mother but the distance between them should be two meters.

- Care of the baby should be taken by a healthy family member.

- The above-mentioned obligations should be fulfilled for 5-7 days (an usual time of infection symptom regression).

b) Procedure for milk expression:

- Every single milk expression requires strict hygiene rules: washing and disinfecting hands before and after touching the milk pump and washing and disinfecting the milk pump after expressing (or using "one-day" sets). Feeding the baby from the bottle should be performed by a healthy family member.

According to the Polish Lactation Study Centre guidelines [18]:

a) If a healthy mother came back from a country where there are infection cases (in the last 14 days) or in the last 14 days she had a direct contact with a person infected with SARS-CoV-2 or a person suspected of being infected (under quarantine) or she was informed by the sanitary-epidemiological station that she had a contact with a confirmed COVID-19 case, the rules are as following:

- Contact a sanitary-epidemiological station or a free-of-charge hotline (for Poland country area 800-190-590). 
- Also contact a GP (the list of clinics: http://www. nfz.gov.pl/).

- Observe the flu-like symptoms and measure the body temperature twice a day.

- Limit personal contacts, if possible.

- Stay at home.

- Wash hands rigorously before every single contact with the infant, especially before breastfeeding or milk expressing.

- Breastfeed or feed the infant expressed milk while strictly obeying the hygiene rules.

b) Mother with confirmed COVID-19 infection, staying home [18]:

- Contact a sanitary-epidemiological station or a free-of-charge hotline (for Poland country area 800-190-590).

- Also contact a GP (the list of clinics: http://www. nfz.gov.pl/).

- Isolate from family members (separate bathroom if possible, separate towels, cutlery, dishes, handles, and worktop disinfection).

- Wash hands for at least 30 seconds, using a detergent or an alcohol-based disinfectant.

- Use a disposable face mask during breastfeeding.

- Between breastfeeding, the infant may stay in one room but the distance between them should be two meters; additionally, a curtain may be used.

- Isolation from baby may be required (depending on the mother's general condition).

- If isolation is required, the milk expressing rules described elsewhere in the guidelines should be followed [19]. Authors affirm that passing on the milk from a mother who is hospitalized or isolated in hospital to her infant staying home may be difficult. They suggest sustaining the lactation.

- Wash and disinfect hands before and after touching the milk pump, and wash and disinfect the milk pump after expressing (using "one-day" sets, if possible).

- Feeding the baby from the bottle should be performed by a healthy family member.

c) Mother with confirmed COVID-19 infection, staying in hospital (when the infant stays at home):

- Keep the lactation process by a regular milk expression.

- Take under consideration that feeding the infant its mother's milk may be impossible because of organization and safety rules.

- Feed the infant the human milk from the human milk bank or sufficient milk formula.

- After hospitalization or isolation, breastfeed according to the rules described elsewhere in the guidelines [19].
The current outbreak of COVID-19 has become the most serious public health emergency at this time. Though the majority of cases are seen in the adult population, newborns and children seem not to be exempted from the epidemic. Since there are only a few cases of SARS-CoV-2 infection in neonates, there is no equivalent-in-meaning evidence to support the possibility of vertical transmission. Clinical presentation in neonates is not specific, and the commonly observed symptoms are temperature instability, respiratory distress, poor feeding, lethargy, vomiting, and diarrhea [20].

\section{CONCLUSIONS}

The new SARS-CoV-2 pandemic has caused unprecedented and serious restrictions. Our knowledge and understanding are updated day by day, but pregnant, delivering, and breastfeeding women affected by the COVID-19 infection need our efficient and responsible response at this moment in time.

We believe that our collaborative research effort can hold safe and unharming procedures and recommendations. We want to share our experience and are looking for other countries guidelines to improve our everyday care, based on the evidence-based medicine.

\section{Conflicts of interest}

The authors declare no conflicts of interest with respect to the authorship and/or publication of this article.

\section{REFERENCES}

1. The Medical Technologies and Rating Assesment Agency (Agencja Oceny Technologii Medycznych i Taryfikacji - AOTMiT). Recommendations in COVID-19. Polish diagnostic, therapeutic and organizational in the field of infected or being in high-risk of infection individuals care guidelines. Version 1.1 - 25.04.2020.

2. Wang $L$, Shi $Y$, Xiao $T$, et al. Chinese expert consensus on the perinatal and neonatal management for the prevention and control of the 2019 novel coronavirus infection (First edition). Ann Transl Med. 2020.

3. Royal College of Obstetricians \& Gynaecologists. Coronavirus (COVID-19) Infection in Pregnancy. Information for healthcare professionals. Version 9: Published Wednesday, 13th May, 2020. https://www.rcog.org. uk/coronavirus-pregnancy (15.05.2020).

4. Royal College of Obstetricians \& Gynaecologists. Coronavirus (COVID-19) Infection in Pregnancy. Information for healthcare professionals. Version 11: Published Friday, 24th July, 2020. https://www.rcog.org.uk/coronavirus-pregnancy (11.09.2020).

5. The Polish Government online legal acts system. http://prawo.sejm.gov. pl/isap.nsf/DocDetails.xsp?id=WDU20200000433 (10.09.2020).

6. The Polish Government online legal acts system. http://prawo.sejm.gov. pl/isap.nsf/DocDetails.xsp?id=WDU20200000491 (10.09.2020).

7. Ziarnik M, Sosnowska J, Chmaj-Wierzchowska K, et al. COVID-19-epidemiology, clinical picture and the management of pregnant woman and her newborn baby. Standardy Medyczne/Pediatria. 2020; 17: 118-129.

8. The Polish Perinatal Medicine Association. http://ptmp.edu. $\mathrm{pl} /$ najnowsze-wytyczne-i-stanowisko-ekspertow-w-sprawie-zakazenia-wirusem-covid-19/ (10.09.2020).

9. The national obstetrics, gynecology and perinatology consensus regarding to the perinatal care during the epidemic state. Update. Issued: 14th May 2020.

10. Stanczyk P, Jachymski T, Sieroszewski P. COVID-19 during pregnancy, delivery and postpartum period based on EBM. Ginekol Pol. 2020; 91(7): 417-423, doi: 10.5603/GP.2020.0106, indexed in Pubmed: 32779163. 
11. The Council of Ministers Regulation including the face and nose covering order. http://dziennikustaw.gov.pl/D2020000067301.pdf (12.09.2020).

12. The Childbirth with Dignity Foundation official statement regarding to the Ministry of Health regulation including the covering the face and nose during the childbirth order. https://www.rodzicpoludzku. pl/aktualnosci/1416-pismo-do-ministra-zdrowia-dotyczace-obowiazku-zakrywania-ust-i-nosa-podczas-porodu.html.

13. The Ministry of Health statement regarding to the Childbirth with Dignity Foundation complaint. https://www.rodzicpoludzku. pl/aktualnosci/1416-pismo-do-ministra-zdrowia-dotyczace-obowiazku-zakrywania-ust-i-nosa-podczas-porodu.html.

14. The national obstetrics \& gynaecology consultant, the national perinatology consultant recommendations regarding to the family birth. Update. Published: 11th May 2020. https://www.gov.pl/web/zdrowie/zalecenia-dotyczace-porodow-rodzinnych.

15. Puopolo KM, Hudak ML, Kimberlin DW, Cummings J. INITIAL GUIDANCE: Management of Infants Born to Mothers with COVID-19. American Academy of Pediatrics Committee on Fetus and Newborn,
Section on Neonatal Perinatal Medicine and Committee on Infectious Diseases. 2.04.2020

16. https://www.who.int/emergencies/diseases/novel-coronavirus-2019/question-and-answers-hub/q-a-detail/q-a-on-covid-19-pregnancy-and-childbirth (15.09.2020).

17. https://www.cdc.gov/coronavirus/2019-ncov/need-extraprecautions/pregnancy-breastfeeding.html?CDC_AA_refVal= https\%3A\%2F\%2Fwww.cdc.gov\%2Fcoronavirus\%2F2019-ncov\%2Fpr epare\%2Fpregnancy-breastfeeding.html.

18. Nehring-Gogulska M, Żukowska-Rubik M. Breastfeeding and mother's milk feeding during SARS-Cov-2 pandemic. Published: 7th May 2020. http://cnol.kobiety.med.pl/wp-content/uploads/2020/05/Algorytmpost\%C4\%99powania-na-czas-pandemii-8.05.2020.pdf (18.09.2020).

19. The mother's milk sourcing from the infected, hospitalized, COVID-19 mother, isolated from her infant 28.04.2020.

20. Kallem VR, Sharma D. COVID 19 in neonates. J Matern Fetal Neonatal Med 2020 [Epub ahead of print]: 1-9, doi: 10.1080/14767058.2020.1759542, indexed in Pubmed: 32419544. 